\title{
About Safety During Landing Aircraft of the Helicopter Type on Unprepared Ground
}

\author{
Viktor G. Mashkov and Vladimir A. Malyshev* \\ Military Education and Research Centre of Military-Air Forces \\ "Military-Air Academy \\ named after Professor N.E. Zhukovsky and Yu.A. Gagarin" \\ 54a Starykh Bolshevikov Str., Voronezh, 394064, Russia
}

Received 27.02.2018, received in revised form 15.01.2019, accepted 23.04.2019

In the article the peculiarities landing a helicopter on a snowy (dusty) area and analysis the security when boarding an aircraft of the helicopter type on unprepared ground. Conditions insufficient visibility when landing in this way are one of the key problems. Since when landing on snow-covered or dry ground because the air jet from the rotor of the helicopter rises solid suspension, which critically reduces the horizontal and vertical visibility and can lead to an incorrect assessment by the crew the spatial position of the helicopter relative to the ground, in addition, unnoticed can remain obstacles in the landing zone (large stones, movable and stationary objects). In addition, when there is insufficient light or adverse weather conditions in the landing zone can be buildings, structures, masts power lines, trees, bushes, etc. Security analysis showed that the aircraft landing helicopters on unprepared ground is a serious problem. The solutions in the field synthetic vision technologies, for the safe landing of the helicopter, which allow to form a three-dimensional image the landing zone through a snow or dusty vortex, lidar (laser location), $W$-band radars and other developments, are outlined. The materials the article are practical value to specialists dealing with the issues of helicopter landing in remote forest, mountainous areas, the Arctic zone, etc.

Keywords: safe landing, landing of the helicopter, unprepared platform, blind landing.

Citation: Mashkov V.G., Malyshev V.A. About safety during landing aircraft of the helicopter type on unprepared ground, J. Sib. Fed. Univ. Eng. technol., 2019, 12(6), 724-732. DOI: 10.17516/1999-494X-0172.

(c) Siberian Federal University. All rights reserved

This work is licensed under a Creative Commons Attribution-NonCommercial 4.0 International License (CC BY-NC 4.0).

* Corresponding author E-mail address: mvgblaze@mail.ru 


\title{
О безопасности при посадке воздушного судна
}

\section{вертолетного типа на неподготовленные площадки}

\author{
В.Г. Машков, В.А. Малышев \\ Военный учебно-научный цеентр Военно-воздушных сил \\ «Военно-воздушная академия \\ имени профессора Н.Е. Жуковского и Ю.А. Гагарина» \\ Россия, 394064, Воронеж, ул. Старых Большевиков, 54 а
}

В статье приведены особенности посадки по-вертолетному на заснеженную (пыльную) площадку и анализ безопасности при посадке воздушного судна вертолетного типа на неподготовленные площадки. Условия недостаточной видимости при посадке таким способом являются одной из ключевых проблем, поскольку при посадке на заснеженный или сухой грунт из-за воздушной струи от несущего винта вертолета поднимается твердая взвесь, что критически снижает горизонтальную и вертикальную видимость и может привести $\kappa$ неправильной оценке экипажем пространственного положения вертолета относительно земли; кроме того, незамеченными могут остаться препятствия в зоне посадки (крупные камни, подвижные и неподвижные объекты). При недостаточной освещенности или в сложных метеорологических условиях в зоне посадки могут находиться здания, сооружения, мачть линии электропередач, деревья, кустарники и т.д. Анализ безопасности показал, что посадка воздушного судна вертолетного типа на неподготовленные площадки является серьезной проблемой. Обозначены решения в области технологий синтетического зрения для безопасной посадки вертолета, которые позволяют формировать трехмерное изображение зоны посадки сквозь снежный или пыльный вихрь, лидары (лазерная локащия), радары W-диапазона и другие разработки. Материалы статьи представляют практическую иенность для специалистов, занимающихся вопросами посадки вертолета в труднодоступной лесной, горной местности, арктической зоне и т.д.

Ключевые слова: безопасная посадка, посадка вертолета, неподготовленная площадка, слепая посадка.

\section{Introduction}

Currently, the development safe landing systems for helicopters is one the priorities, which is engaged in a large number firms in our country and abroad. Research has different directions of development. In this article the analysis safety at landing of aircrafts (AF) of helicopter type, in the conditions limited visibility on the snow-covered (dusty) platform is carried out.

\section{Special features of helicopter landing on snow-covered (dusty) ground}

The most difficult and dangerous stage the flight is landing. With the operating engines, the flight properties of the helicopter allow you to land in two ways-by helicopter or by plane.

The determining factor in choosing a landing method is the nature the landing site, the helicopter's load and the available power the main rotor (MR) on the take-off mode of the engines. The main characteristics the runway in this case are: its size, the height the surrounding obstacles, the strength the soil, the presence of slopes, obstacles, snow (dust). The available thrust depends on such characteristics as: the height the site above sea level, atmospheric conditions, wind direction and speed. 
If the available thrust MR allows you to hang the helicopter at the required level, landing is performed in a helicopter.

If it is impossible to make a hang at the required level due to lack of available thrust MR, or for educational purposes, landing is carried out in a second way by plane. This method allows you to increase: the range the flight, by increasing the amount of fuel filled, or the weight of the cargo transported. The total flight weight of the helicopter in any case should not exceed the maximum permissible in the presence all other favorable conditions.

In any case, landing is performed against the wind if possible. This increases the reserves of the helicopter engine power, longitudinal and control the permit and generally contributes to the safety landing. In the absence such capabilities allowed the landing with the side or the wind not exceeding the specified value the speed Instruction to the crew.

When landing in a helicopter, after reducing the helicopter to a height of $100 \mathrm{~m}$ on the landing line, a smooth deviation of the control knob (KC) «on itself» begins to reduce the forward speed, so that at an altitude of $60 \ldots 50 \mathrm{~m}$ it was about $60 . .50 \mathrm{~km} / \mathrm{h}$.when planning to achieve a speed of less than $60 \mathrm{~km} / \mathrm{h}$, the required power increases and the vertical speed increases. Therefore, a smooth increase collective pitch maintain a constant vertical speed of $2 \ldots 3 \mathrm{~m} / \mathrm{s}$, and the closer to the ground and extinguish reduce its forward speed. It should be borne in mind that with a sharp increase in the «STEP-GAS» is preteenie MR and increase ahead of an increase in the limit torque, causing the helicopter can spontaneously decrease, and in the presence a crosswind entry is possible in the regime of spontaneous rotation [7].

When you increase collective pitch occurs increase as the vertical component the total thrust of MR and its horizontal component. Because by this time the cone of rotation moves back, the horizontal component along with the braking action creates Cabriole moment. As you increase collective pitch, to ensure uniformity the quenching rate and preservation pitch angle constant, $\mathrm{KC}$ deviates from itself.

After hovering helicopter performed vertical reduction in speed to the moment landing no more than $0,2 \mathrm{~m} / \mathrm{s}$ with a smooth reduction the total step, not allowing any lateral movement or displacement back, especially at the time touching the wheels the earth.

The decrease in landing on the limited grounds must run at a speed not exceeding $1 \mathrm{~m} / \mathrm{s}$, especially in the case maximum loading of the helicopter.

When landing on limited forest glades, it is necessary to take into account that at the moment hovering over the forest, the wind creates some additional traction of MR, which decreases as the influence the wind decreases and therefore requires an additional increase in capacity.

As the helicopter hangs with the right roll, the landing is performed first on the right wheel then the left and then on the nose.

The overall step is reduced only when the helicopter is stable on hard ground all the wheels of the chassis, in order to avoid rocking and tilting the helicopter on the ground.

When landing in a helicopter on a snowy (dusty) area, there are a number of features. In such circumstances, the landing should only be performed when the visibility the landmarks or the natural horizon with advanced hovering above the ground. Hanging with this planting is done on top, free from snow (dusty) clouds lifted jet from MR. Takeoffs and landings by helicopter, hovering, flying in the absence of horizontal and vertical visibility is prohibited. 
To perform landing on a snow-covered (dusty) platform, the landing weight of the helicopter must ensure hanging outside the zone influence the earth (without the use an airbag).

Snow or dusty whirlwinds, which worsen the visibility of the crew, arise around the helicopter when landing on snow-covered, sandy or dusty sites. During the landing process, the helicopter enters the snow (dusty) cloud, while the visibility the landmarks planned for planting with their further exclusion worsens. If the visibility landmarks (details of the relief) continues to deteriorate decline is stopped by hanging and inflating the snow (dusty) cloud. After hovering, the crew continues to decrease the helicopter smoothly in such a way that by the time deterioration of horizontal visibility was provided reliable vertical visibility until the moment landing, or there is visual contact with the ground through the front glazing. Otherwise, vertical descent and landing are prohibited, as well as the search for landmarks by moving from the helicopter's ground surface to the sides are prohibited [7]. When landing in low visibility conditions or possible deterioration of the crew commander must be in constant readiness to move to pilot on instruments.

Landing on a snow-covered platform by a helicopter is allowed to be carried out at a thickness of snow cover less than $50 \mathrm{~cm}$, and on its surface there is a dense fast, which excludes the possibility forming a snow vortex [5]. In the absence of horizontal and vertical visibility and loss the reference point by the crew, the reduction is stopped and immediately goes to the second round. It is also not allowed lateral displacements, and reversals in the decline, especially in the moment landing. A particular danger when landing on snow-covered area represent the lateral displacement when the thickness of snow over $10 \mathrm{~cm}$.

After landing, gradually reduce the overall step to a minimum value, only making sure that the helicopter is firmly on the surface. Because hidden under the snow uneven terrain may occur heeled helicopter, in this case, increase collective pitch to separate the helicopter from the ground surface to a height of $0,5 \mathrm{~m}$ to $1 \mathrm{~m}$ and select a new landing site, if allows horizontal visibility, and then make the landing [7]. In winter there is a possibility use as a temporary landing pads for helicopters ice cover of rivers and lakes.

At landings of the helicopter in unfamiliar areas are recommended to be planted on-Board equipment on the ground, which will inspect the site and determine its suitability for landing, because the control passage can not see under the snow or grass cover hidden dangerous irregularities, large stones, silt small stones, etc.

It is necessary to carry out a check pass over or near the sites when they are located in the riverbeds and on the banks mountain rivers in order to determine its suitability for landing, to clarify its barometric height, direction and wind speed.

Selection smooth footage during landing in the riverbed, as well as the approach and landing must be performed with high caution, because the stream may be sediment fine silt, pebbles, bushes and grass, which when approaching land, can be delayed by the jet from the screw closing the overview the place landing, to get to the motor or screw. Before planting, the hang must be performed at a height of at least $1,5 \mathrm{~m}[6]$.

Before landing on the top, it is also recommended to perform a check pass over the site. It is advisable to carry out the passage with excess over the platform $20 \ldots 30 \mathrm{~m}$ and at a speed of $80 \ldots 100 \mathrm{~km} / \mathrm{h}$. 
The direction the wind at the ground is determined by firing a rocket launcher or dropping a smoke bomb from a helicopter. The direction the wind and its approximate speed can be determined by the smoke from the checker or rocket.

It is necessary to remember that on passes and high tops the direction and speed of a wind are subject to sharp change [6].

During the landing at the stage approach to the landing zone, in addition to overcoming the degraded visual environment (DVE), when landing on unprepared sites, there is a need to accurately determine the relief, type and characteristics the underlying surface. For example, when planting on snow and ice soil, it is necessary to know the thickness the snow and ice cover, its density and soil composition in order to avoid the helicopter from falling under the ice or into the snow. It should be remembered, slopes greater than $15^{\circ}$ and a roughness height of more than $0,5 \mathrm{~m}$ are dangerous for helicopter landings, especially in windy conditions [8].

In order to avoid a snowdrift experienced pilots put the car to «crow». Recommend this method landing can not be every pilot, since the landing is performed without hovering over the site, while the entry is performed at high speed. Vertical and horizontal velocity decrease to zero at the moment touching the main wheels the chassis. Touch is with a large pitch angle, followed by lowering onto the nose wheel. Snow (dusty) vortex due to the high speed remains behind all the time and only after lowering the bow wheel covers the cockpit. The landing «crow» exercise if you cannot execute landing an aircraft, for tactical reasons, with the faults power the power plant (PP) outside the impact zone the land for planting in the helicopter, with emergency landings [4].

One the most difficult elements piloting a helicopter is landing on an unprepared site, since it involves an increased risk accident and human casualties. First of all, the need to land on unprepared sites arises in military aircraft: delivery ammunition, cargo, landing, evacuation in combat conditions. Often it is necessary to plant a helicopter in an unknown or unprepared landing zone or hang directly above it.

When landing on snow-covered or dry ground because the air jet from the rotor the helicopter rises solid suspension, which critically reduces the horizontal and vertical visibility and can lead to incorrect crew assessment the spatial position of the helicopter relative to the ground, in addition, unnoticed can remain obstacles in the landing zone (large stones, movable and stationary objects). When landing or taking off on a dry surface, the term «dusty vortex» (brownout) is used to describe this phenomenon. The term «snowdrift» (whiteout) describes similar conditions during landing or takeoff on a snow-covered surface [6].

The conditions insufficient visibility (lip, eng. degraded visual environment (DVE) is one of the key issues when landing on unprepared sites. Under DVE refers to weak or zero optical visibility the Outback situation, due to any one or several factors: the vortex solid particles, lifted by the helicopter screw, adverse weather conditions (blizzard, smoke, fog, etc.), low illumination. A particular danger is the vortex of solid particles lifted by the helicopter screw.

Landing on unprepared sites in poor visibility conditions (blind landing) cause a significant percentage of aviation incidents and accidents [6].

Thus, it is possible to distinguish two main causes of accidents. The first reason is the lack awareness about the spatial position of the helicopter. The second-insufficient awareness the state the landing zone. Currently, on-Board navigation devices such as GPS, doppler speed meter, inertial 
measuring unit, radio altimeter, gyroscope in general are able to give all the necessary information, but only with good visibility. As for the first reason, most modern radio altimeters do not work well in the snow (dusty) vortex and do not reflect the real rate of decline and altitude above the ground.

With sensors a condition of a zone of landing Affairs are even worse. Existing solutions: weather radar, thermal imaging and TV cameras for viewing through the snow (dusty) vortex are not suitable here, and sensors with high penetrating power are at different stages of technological readiness.

\section{Analysis security when boarding an aircraft helicopter type to unprepared sites}

The analysis of aviation incidents at landing helicopters in poor visibility conditions, allowed to identify the main causes, here are some statistics taken from a variety sources. According to the Department inspection safety of Federal air transport Agency the Russian Federation from 2001 until mid-2014 when landing, there were 24 accidents and 6 accidents of civil helicopters $[3,8]$.

The snow vortex caused 54 accidents and two accidents of helicopters in the period from 1986 to 2006, such data lead the Canadian Armed forces $[1,6,8]$.

On a row with a snow vortex similar statistics are given on a dusty vortex when landing on a sandy surface. During the landing, a dusty vortex caused accidents of helicopters in about $75 \%$ of cases during operations in the middle East (NATO data), 60 crew members were killed and more than 30 special purpose helicopters were disabled in areas with a dry climate in Iraq and Afghanistan from 1990 to 2012 (data of the US Armed forces). An aircraft accident during landing helicopters in poor visibility conditions annually cause material damage to the Armed forces of the United States about 100 million dollars $[1,6,8]$.

47 aircraft accidents (AA) and disasters occurred in the autumn-winter period from 1999 to 2007, which killed 44 crew members and 21 passengers, lost or damaged helicopters: Mi-26T - one; Mi-8 thirty one; Mi-2 - thirteen; Ka-32 - two (data of the Federal service for supervision of transport). The human factor has caused the largest number of accidents. Getting into a Blizzard because the illiteracy the crew have become the reason for 19 aircraft accident, the failure of the crew of the requirements normative documents that need to go on piloting the instrument became the reason collision of helicopters with terrain 6 accidents $[2,8]$.

The main reason for leading to accidents include:

- underestimation and neglect of weather conditions in the area of flights;

- poor quality forecast and assessment of the meteorological situation;

- errors in the technique of piloting;

- lack discipline of the flight crew, expressed in an unjustified desire to continue the landing with the deterioration of weather conditions;

- gross violation of the requirements normative documents;

- illiterate operation by the crew the anti-icing system of the helicopter, not maintaining the minimum safe altitude in contact with difficult weather conditions and the transition to flight on the instruments;

- poor preparation in the autumn-winter period of the airfield and landing sites for flights.

As examples accidents related to loss of visual contact with the ground can result in the following $[2,8]$ : 
- 4 crew members and 2 passengers fortunately didn't suffer as a result accident of the Mi-8T helicopter (sue Komiaviatrans) on January 4, 2004 in the Nenets Autonomous area. The reason was the difficult weather conditions, the crew three times performed a landing approach with a passingside wind behind the right. The associated wind, as the instrument speed decreased, led to a shortage available engine power and to an unintended decrease in the helicopter. The increase in the overall pitch of the rotor at an altitude of 20 meters due to the intensive taking of the control knob «on itself» led to a drop in the rotor revolutions, resulting in the helicopter collided with the ground surface and tilted to the left side. Led to such consequences a combination adverse factors with the lack trained crew to fly in these conditions, this loss visual contact due to drifting snow events with the landing area at low altitude flight, the wrong definition wind direction when landing, the lack monitoring height of flight;

- Crew members and passengers were not injured in the accident of helicopter Mi-8T (FSUE «Tuva Avia») on 25 September 2004. Landing a helicopter on the river spit of the Yenisei river with 10 passengers caused a sharp deterioration in the weather (heavy rain and visibility deterioration). The commander the crew, not being able to turn the aircraft around and go the opposite course, and decided to land the helicopter on the river spit. The car after landing overturned to the side received significant damage to the end of the tail boom (broken end beam) and remained in an inverted position;

- The accident of helicopter Mi-8T (airline «Polar airlines») on 4 October 2004 as a result of loss of visual contact with the ground when landing in the village of Arbenz. The helicopter hit the ground and received significant destruction as a result of the deviation of the aircraft commander handle a cyclic step away from him, creating a pitch dive to minus $20^{\circ}$ with a roll to the left about $15^{\circ}$ for the second round;

- The accident of helicopter Mi-8T (airline «Yamal») on 29 October 2005 in consequence of gross errors in piloting technique and the requirements of FOM and IMF GA-85 g. the aircraft commander when entering the site instead a missed approach due to fog and whiteness the underlying surface lost visual contact with the ground, continued the approach and made a collision of the helicopter and HB with the ground;

- Two crew members and three passengers died on 28 March 2006 due to a helicopter collision with the ground as a result the loss by the aircraft commander spatial orientation when entering the site marked with torches. The human factor was the cause the disaster, as the commander of the aircraft did not have access to land on the site with the selection at night;

- The crew and passengers were not injured, the mi-8T helicopter (FSUE Koryak aviation enterprise) is not subject to restoration as it received considerable damages as a result an error the crew commander of the aircraft in the piloting technique when landing in conditions a snow vortex on may 12,2007 . In the highlands performing flight helicopter was in the area heavy snowfall. The loss visual contact the commander the aircraft with the earth's landmarks when trying to land on the site, picked up from the air in the daytime led to a rough landing of the helicopter and overturning to the right side.

\section{Conclusion}

The sad statistics can be continued further, but it is also clear that when landing an aircraft of helicopter type on unprepared sites it is necessary to have on Board a means capable of «seeing» the 
surface the landing, regardless of the time of year, day, weather conditions and other negative factors affecting safety. For example, the author in the literature [8] considered solutions in the field synthetic vision technologies for the safe landing of the helicopter, allowing to form a three-dimensional image the landing zone through a snow or dusty vortex, leaders (laser location), W-band radars and other developments.

Currently, on modern helicopters, the available sensors do not provide all the necessary information to the pilot in difficult weather conditions, since they are not able to effectively scan the landing zone through a snow or sand suspension. In addition, the on-Board navigation devices do not provide an easily readable image at the output, thereby further increasing the load on the pilot.

\section{References}

[1] Rotary-Wing Brownout Mitigation: Technologies and Training. [Электронный ресурс]. Режим доступа: https://www.researchgate.net/publication/234675186_Rotary-wing_Brownout_ Mitigation_Technologies_and_Training - Заглавие с экрана. [Rotary-Wing Brownout Mitigation: Technologies and Training. [Electronicresourse] - Access: https://www.researchgate.net/publication/234675186_Rotary-wing_Brownout_Mitigation_Technologies_and_Training

[2] Авиационные происшествия: обстоятельства и причины. Вертолет, 2007 № 3: [Электронный ресурс]. - Режим доступа: https://coollib.com/b/268442/read\#t8 - Заглавие с экрана. [Aviation accidents: circumstances and reasons. Helicopter, 2007 № 3 [Electronicresourse] Access: https://coollib.com/b/268442/read\#t8

[3] Анализ состояния безопасности полетов в гражданской авиации Российской Федерации в первом полугодии 2014 года. Управление инспекции по безопасности полетов Федерального агентства воздушного транспорта Российской Федерации. [Электронный ресурс]. - Режим доступа: http://special.komimtuvt.ru/d/1905788/d/analiz-bp-v-pervom-polugodii-2014-goda(1).pdf Заглавие с экрана. [Analysis of the state of safety in civil aviation of the Russian Federation in the first half of 2014. The management of inspection of safety of Federal air transport Agency of the Russian Federation. [Electronicresourse] - Access: http://special.komimtuvt.ru/d/1905788/d/analiz-bp-vpervom-polugodii-2014-goda(1).pdf

[4] Вихри враждебные. Ассоциация вертолетной индустрии / В.Ф. Карпов: [Электронный pecypc]. - Режим доступа: https://www.aviaport.ru/digest/2009/02/17/ 167033.html - Заглавие с экрана. [Swirls hostile. The Association of the helicopter industry / V.F. Karpov [Electronicresourse] Access: https://www.aviaport.ru/digest/2009/02/17/167033.html

[5] Особенности взлетов и посадок на пыльных, песчаных или заснеженных площадках: [Электронный ресурc]. - Режим доступа: http://www.svvaul.ru /component/k2/600-osobennostivzletov-i-posadok-na-pylnykh-peschanykh-ili-zasnezhennykh-ploshchadkakh - Заглавие с экрана. [Features of takeoffs and landings on dusty, sandy or snow-covered sites [Electronicresourse] - Access: http://www.svvaul.ru/component/k2/600-osobennosti-vzletov-i-posadok-na-pylnykh-peschanykh-ilizasnezhennykh-ploshchadkakh

[6] Полеты в горах: [Электронный ресурс]. -Режим доступа: http://pandia.ru/text/80/087/40723.php - Заглавие с экрана. [Flights in the mountains [Electronicresourse] - Access: http://pandia.ru / text/80/087/4072-3.php 
[7] Посадка: [Электронный ресурс]. - Режим доступа: https://studopedia.su/16_21971_posadka.html - Заглавие с экрана. [Landing [Electronicresourse] - Access: https://studopedia.su/16_ 21971_posadka.html

[8] Сажаем вертолет вслепую: обзор технологий синтетического зрения: [Электронный pecypc]. - Режим доступа: https://geektimes.ru/post/280278/ - Заглавие с экрана. [We plant the helicopter blindly: a review of synthetic vision technologies [Electronicresourse] - Access: https:// geektimes.ru/post/280278/ 